\title{
An Examination of Gender Differences in Elementary Constructionist Classrooms Using Lego/Logo Instruction
}

SUMMARY. Gender disparity exists in many educational environments despite conscientious attempts to equalize opportunities and outcomes. Research studies indicate females are less likely to effectively engage in the use of technology for problem solving. However, in a two-year study of a Midwest elementary multi-age classroom, researchers studied computer-using activity of grade 1-5 students using Lego/ Logo technologies. Teachers put in practice learning strategies that encouraged both sexes to engage in computer-oriented problem solving. Through an experimental design, observation, and teacher assessment, the results suggest that, in practice, females demonstrate significant gains in self-efficacy using computer technology in this computer-rich classroom and report positive perceptions of self. Girls report more positive assessments of female technological competence and current computer use while boys do not waver from a belief in male technological superiority. Observation and teacher assessment indicate females are solving problems without asking for help. Furthermore, girls suggest that males are not more technologically savvy than they are.

SALLY R. BEISSER is Associate Professor, Teaching and Learning Department, School of Education, Drake University, Des Moines, IA 50311 (E-mail: sally.beisser@ drake.edu).

[Haworth co-indexing entry note]: "An Examination of Gender Differences in Elementary Constructionist Classrooms Using Lego/Logo Instruction.” Beisser, Sally R. Co-published simultaneously in Computers in the Schools (The Haworth Press, Inc.) Vol. 22, No. 3/4, 2005, pp. 7-19; and: Classroom Integration of Type II Uses of Technology in Education (ed: Cleborne D. Maddux, and D. LaMont Johnson) The Haworth Press, Inc., 2005, pp. 7-19. Single or multiple copies of this article are available for a fee from The Haworth Document Delivery Service [1-800-HAWORTH, 9:00 a.m. - 5:00 p.m. (EST). E-mail address: docdelivery@ haworthpress.com].

Available online at http://www.haworthpress.com/web/CITS

(c) 2005 by The Haworth Press, Inc. All rights reserved. 
Girls also indicate that boys were not more likely to be adult computer users. On the other hand, boys report only a slight shift in their gendered beliefs. [Article copies available for a fee from The Haworth Document Delivery Service: 1-800-HAWORTH. E-mail address: <docdelivery@haworthpress. com> Website: <http://www.HaworthPress.com> (0) 2005 by The Haworth Press, Inc. All rights reserved.]

KEYWORDS. Lego/Logo technologies, effective strategies of computerusing teachers, computers and female competence

\section{STATEMENT OF THE PROBLEM}

Gender disparity exists in educational environments despite conscientious attempts to equalize opportunities and outcomes. Sex differences persist in attainment of careers in the related fields of mathematics, science, and technology (AAUW, 1998; Beisser, 19992000; Meece \& Eccles, 1993; Roblyer, 2000; Sutton, 1991; Turkle, 1988; Wellesley College Center for Research on Women, 1992). Much effort has been expended to change the patterns of attitudes and behaviors that lead to unequal outcomes (AAUW, 1998; Fennema, 1990; Kahle \& Meece, 1994).

Despite gains in policy inviting equal opportunity for females such as Title IX initiatives (1997), academic status and opportunities lag for girls in use of technology. The American Association of University Women report, Gender Gaps: Where Schools Still Fail Our Children (1998), indicates that females still lag behind males in their interest in computer studies, enrollment in computer courses, and decisions to major in computer sciences. Women remain underrepresented in technology-based careers, such as engineering, computer studies, and medicine (Klein \& Ortman, 1994; Mark, 1992). If females are to be full participants in their learning environments and in the workplace, they must possess basic and necessary technology skills and knowledge for participation and advancement.

\section{RECOMMENDATIONS FROM THE LITERATURE}

Recommendations from a study of adolescent females (Beisser, 1999, p. 4) strongly recommend cultivating early childhood experi- 
ences and school exposure to computers for activities requiring logic, reasoning, and higher level thinking in order to encourage girls to use technology. Use of technology is compromised in classrooms that do not foster problem solving. Casey and Tucker (1994) found successful classrooms are focused on problem-based and planning strategies more systematically and intensely than is the case in most classrooms. Creative students are constantly questioning and curious, enjoy figuring things out, seek out challenges, are persistent, approach tasks in a flexible way, are self-reliant, and feel confident about themselves as learners and risk takers. Students who are effective planners think things through before they act, gather, and organize materials in an appropriate way, and systematically approach different parts of the task.

The teacher's role in a problem-centered classroom is critical. "Children are natural question-askers. But whether they continue to ask questions-and especially to ask good questions-depends largely on how adults respond to their questions" (Sternberg, 1994, Phi Delta Kappan, p. 136). Not every teacher teaches problem solving. Moursand (2002) asserts the notion that "every teacher teaches problem solving" is a haphazard approach to learning, and that the result is that most students do not get a coherent introduction to problem solving. Learners must have a clearly defined initial situation, a clearly defined goal (a desired end situation), a clearly defined set of resources, and ownership to use knowledge, skills, and energies to achieve the desired final goal. In response to these findings, and with clear understanding of effective pedagogy, five teachers in one multi-age school have found something that works.

\section{EFFECTIVE USE OF COMPUTERS IN A “CONSTRUCTIONIST" CLASSROOM}

Constructivism is loosely defined in educational literature, referring to ill-defined concepts such as constructing knowledge, creating meaningful learning, problem solving, reflective construction, or metacognition (Maddux $\&$ Cummings, 1999). Despite vague understanding and implementation of constructivist theory, many teachers have been drawn to better practices whether they clearly understood the term or not. However, the teachers in this study moved from constructivist generalizations to constructionist (Harel \& Papert, 1991) theory and practice. Constructionism is a theory of learning based on two different notions of construction of knowledge. First, it is grounded on the idea that chil- 
dren learn by actively constructing new knowledge, not by having information dispensed to them (Piaget, 1924). Second, constructionism asserts that effective learning takes place when the learner is engaged in constructing personally meaningful artifacts using manipulatives such as creating computer animations, robots, plays, poems, icons, objects, or pictures representing one's own learning. As a collaborator in this research initiative, Seymour Papert, Massachusetts Institute of Technology (MIT) professor, has dedicated his retirement years to help teachers and students use Lego ${ } / \operatorname{Logo}$ technologies as intelligent manipulative tools to nourish children's active construction of knowledge. This study results from Dr. Papert's influence and leadership with interim visits with the teachers and children in this research project.

Learning with computers and using the Logo programming language is a daily activity for approximately 100 students in one, grade 1-5 elementary school. Children in each of these five classrooms have daily blocks of time to work in a technology-rich environment filled with Mindstorms ${ }^{\mathrm{TM}}$ kits and MicroWorlds ${ }^{\circledR}$ for constructing and programming, thinking and problem solving, developing and sharing expertise. Papert developed the Logo computer language in the 1970s as an "intelligent tool" to develop logical thinking and reasoning. The Lego® Company marketed Mindstorms ${ }^{\mathrm{TM}}$ kits, so named after Papert's seminal book (1980). Using Legos ${ }^{\circledR}$ as intelligent tools, children build machines out of the Lego ${ }^{\circledR}$ pieces, connect their machines to a computer, and write Logo programs to control the machines. With MicroWorlds ${ }^{\circledR}$ software, students use mathematics for creating pictures, animations, music, games, and simulations on the computer. Papert says, "Given a good programming language, I see children struggling to make a program work in a way that they seldom sweat at their paper-and-pencil mathematics" (1999, p. 4). Papert promotes computers as "Children's Machines" in his work on Rethinking School in the Age of the Computer (1993).

\section{RESEARCH QUESTIONS}

Four research questions driving this study were: (a) Do elementary girls and boys demonstrate different learning behaviors as they respond to multiple computer programming activities in a computer-rich classroom? (b) Does a computer-rich environment enhance female competence or confidence in using computer technologies? (c) Do boys view themselves as more competent or confident than girls in using com- 
puter technologies? (d) Do teachers use instructional or management strategies that enhance self-efficacy of students in a computer-rich environment?

\section{METHODOLOGY}

\section{Participants}

All students $(N=99)$ in the grade $1-5$ school completed a two-page questionnaire designed to assess student attitudes about using technology for learning and relevance of technology in learning and future work. Classroom teachers and university research assistants helped students understand directions, responded to any questions, and occasionally assisted in spelling words in the written response section. Students in grades one and two worked in small groups to respond to the survey questions while the upper grades completed the survey as a whole class. Five classroom teachers were observed for ways in which they designed and assessed classroom activities using computer technologies, promoted problem solving using Lego/Logo programming, and interacted with their elementary students.

\section{Instruments}

The student questionnaire (obtainable from the senior author at address sally.beisser@drake.edu) consisted of 20 questions with responses based on a four-point Likert-like scale. Response categories were 1 = strongly disagree, $2=$ disagree, $3=$ agree, and $4=$ strongly agree. In addition, three narrative responses described a "positive experience with computers," a "frustrating experience with computers," and designation of "someone who was good at using computers." Questionnaires were developed in conjunction with the teachers and were administered by the teachers during the fall and spring semester of the 2001-2002 school year. Survey data were analyzed in SPSS. Use of $t$-tests allowed analysis of specific attitudinal changes in girls and boys as well as comparisons by gender. A second instrument, a teacher observation form allowed researchers to conduct weekly observations of teacher-to-student interaction and instruction using computer technology in effective ways. The observation form served as a cross check sheet to determine instructional techniques that represent the most frequently observed behaviors from all participating teachers. 


\section{Procedures}

Data from interviews with the five teachers were analyzed qualitatively to extract instructional strategies typifying behaviors that resulted in positive learning experiences in the classroom. Furthermore, the research team observed and categorized the teaching and management strategies of the teachers using 30-minute observational periods to cross check teacher reports. Researchers, including graduate and undergraduate students, collected data in weekly visits to the grade 1-5 multi-age classroom for a two-year observational study. By examining sex-based learning activities in a classroom using computers for problem solving, researchers investigated possible differences in student behavior using the construction and programming materials in a technology-rich school.

\section{METHODS OF DATA ANALYSIS}

\section{Qualitative Results}

Indeed, elementary girls and boys demonstrate different learning behaviors in a computer-rich classroom as addressed in research question (a). Even with the same construction and building materials and programming instruction and high expectations for all students, females responded differently from the males. Females were initially intent on building stereotypical structures such as houses and social settings. Girls were content to make aesthetically pleasing structures such as houses with rooms. They needed specific encouragement from the teachers to use the materials to build and program structures to function using moving parts. In time, however, they were successful in programming structures to move. Males, on the other hand, made things move from the onset, even if structures were loosely constructed and were easily demolished upon impact. Females more readily worked in pairs or teams, while males worked more independently or alone in daily activities. Females were more inclined to refer to written directions in the Lego/Logo booklets that accompanied the building components. Males were more likely to assemble pieces as they invented final products that moved with wheels and gears. In completing required "progress folios" to describe student accomplishments of the day, females were more meticulous in writing down or drawing their action steps, detailing what they had learned in relation to programming, than males who used 
fewer words in the analysis of their progress. However, both males and females valued extra time to complete their projects and responded with a collective groan when it was time to put the construction and computer programming materials away. It seems clear that females responded favorably to increased attention to skill-building competence and the development of personal confidence as a result of the technology-rich classroom environment as addressed in research question (b).

In addition, elementary students responded to effective teaching strategies (research question d) that invite all children, especially the females, to become more efficacious problem solvers. From interviews with the teachers and observations of their direct work with the students, 11 strategies have emerged that, while aimed at all students, specifically assisted the females in using computer technology in effective ways. The following teacher behaviors were evident through the weekly observations of the teachers in the technology-rich school with a high investment in tenacious learning episodes of the students. Of these 11 teacher strategies, 8 were general instructional strategies, while 3 were specific to enhancing gender competencies.

General teaching strategies using technology effectively. Extended Time. Teachers use relatively long lengths of time for students to sustain work on existing technology projects. When students were deep in thought and planning, teachers allowed them to continue work on projects after the perceived time of closure. Teachers planned in advance for longer periods of time for extended technology projects to be developed. Inviting Complex Tasks. Teachers direct students to make multiple-page MicroWorlds projects with animation or increased complexity in design. They require kids to "go beyond" or take the next steps to "make something move" in Lego/Logo or MicroWorlds, thus inviting programming opportunities. Purposeful Grouping of Students. Teachers group "females with females," linking those with more experience and pair students with expertise with younger students for support in using Lego/Logo and MicroWorlds programs. They also group "females with males" with programming and Lego/Logo experience, and expertise as pairs. Longer Processing or Wait Time. Teachers employ longer wait time after asking questions to get a response from students. They also wait longer after getting a response before moving on to more conversation or questioning. They give kids obvious time to process ideas or to think about their learning. Students Acting as Experts. Teachers engage students in assisting others as the "expert" when using technology. Teachers promote student expertise, rather than the teacher as expert. Probing Questions. Teachers thoughtfully ask probing questions 
such as, Can you tell me about what you are doing? Explain what you just did. How does this work? Was this successful? Why or why not? What will you try next? Show me how this goes? Was there a problem that you solved? If so did that solve a problem? What will you try next? Why do you think this will work? Authentic Assessment. Journaling and reflection are daily experiences. Teachers manage "Progress Folios" that include reflective journaling and representation of work and problem-solving experiences that are kept over time. Goals are established at peer-led parent/teacher conferences in the fall and spring and are agreed upon by the student, parent, and teacher. Positive Technology Self-Talk from Teachers. Teachers convey their own success levels/positive experiences with features of Lego/Logo and MicroWorlds programs technology (e.g., troubleshooting success). Teachers portray a general positive attitude using technology (not related to the Lego/Logo and MicroWorlds) such as remaining positive in the face of crashes, memory loss, programming problems, or technical problems, or when troubleshooting does not work.

Gender specific strategies in using technology effectively. Encouraging Construction Behavior for Both Genders. Teachers encourage both boys and girls, as individuals, to build with Lego/Logo or other construction materials in clearly defined situations that promote a desired end situation using a clearly defined set of resources, and ownership to use knowledge, skills, and energies to achieve the desired final goal. Specific Female Encouragement. Teachers direct female students to construct or program (e.g., make a vehicle, construct something that is "stronger" or that won't crash when you operate it). For example, they ask girls to program a construction with the "yellow brick." Generally, they encourage girls to move away from stereotypical constructs such as a "house, flowers, etc.," or at least to implement programming with these designs. Whole Group Talks on Gender Diversity and/or Individual Differences. Teachers organize group conversations about genderrelated issues, such as talking about individual differences that exist in the world, or hold class meetings about gender issues specifically. These may be teacher directed or student initiated. They give all students a chance to express opinions with regard to differences in the large group setting.

According to the study's qualitative accounts, girls are thriving in this environment. One teacher said, "When we first started Lego/Logo computer work in our class, the girls played with the Lego building blocks to make only houses and families. But now, we are observing that girls not only work with gears and motors and pulleys just like the 
boys do, but express intentions to use programming language." Females in this study are experiencing success using computer technology for learning and creative activity, and express intentions for future use of technology. Outcomes from the study include documentation of student success and self-efficacy of females in the classroom using computer technology in meaningful ways.

Males are thriving too. However, the primary difference is that they continue to think they are very competent in using technology for problem solving at school as well as in their futures. They consider themselves to be superior to the girls, but the girls do not see it this way. They report that their competence is strong and they do not report needing to be helped in the face of technological challenges and view themselves as equally competent computer-users at school as well as in the future. Boys continue to create vehicles that crash, and upon demolition, recreate them and reprogram them. They are still consulted as experts more frequently than the females, but girls disagree that the boys hold the market on expertise. Even if the girls create stereotypical scenes such as "Happy Joes" pizza kitchens, a bakery, amusement rides in a theme park, they are making moveable operations through programming.

\section{Quantitative Results}

Research question (c) compared both male and female competence and confidence in using computer technologies in their classrooms. There were observable differences. Table 1 indicates significant pretest differences between girls and boys on seven of the ten technological learning relevance items. It was evident that neither group believed that computer use was gendered, but girls were less supportive (girls' mean $=$ 1.76 ; boys' mean $=2.41$ ). However, when it came to adult computer use, boys and girls believed that they would be more likely than their counterparts to use computers. Boys reported more agreement that they used computers to build things more so than girls did (boys' mean = 3.08; girls' mean $=2.56$ ). On average, boys reported that males played with computer games more than girls did (mean $=2.83$ ), but girls disagreed (mean $=2.16$ ). The groups disagreed on boys being more technologically sophisticated than girls were (boys' mean $=2.61$; girls' mean $=1.85)$. Boys believed that girls asked for technological help more $($ mean $=2.80)$, while girls did not think so $($ mean $=1.81)$.

In general, boys held attitudes that were favorable to their own sex, with the exception of computer use in childhood. For the most part, girls did not buy into boys' technological superiority. However, when it 
TABLE 1. Relevance of Technology for Learning and Future Work (Pretest Findings)

\begin{tabular}{|c|c|c|c|c|c|c|c|}
\hline & \multicolumn{2}{|c|}{ Boys } & \multicolumn{2}{|c|}{ Girls } & \multirow{2}{*}{$\begin{array}{c}\text { Mean } \\
\text { Difference }\end{array}$} & \multirow[t]{2}{*}{$t$} & \multirow[t]{2}{*}{$p$} \\
\hline & $M$ & $S D$ & $M$ & $S D$ & & & \\
\hline $\begin{array}{l}\text { 1. Boys use computers } \\
\text { more often than girls do. }\end{array}$ & 2.41 & 1.22 & 1.76 & 1.03 & 0.65 & 2.800 & 0.006 \\
\hline $\begin{array}{l}\text { 2. Boys play with more } \\
\text { computer games than } \\
\text { girls do. }\end{array}$ & 2.83 & 1.17 & 2.16 & 1.15 & 0.67 & 2.806 & 0.006 \\
\hline $\begin{array}{l}\text { 3. Boys use computers } \\
\text { more than girls to build } \\
\text { moving things or use } \\
\text { motors. }\end{array}$ & 3.08 & 1.17 & 2.56 & 1.10 & 0.52 & 2.213 & 0.029 \\
\hline $\begin{array}{l}\text { 4. Girls ask for help } \\
\text { more often than boys } \\
\text { in using technology. }\end{array}$ & 2.80 & 1.16 & 1.81 & 1.02 & 0.99 & 4.246 & 0.000 \\
\hline $\begin{array}{l}\text { 5. Boys are better at } \\
\text { using technology than } \\
\text { girls. }\end{array}$ & 2.61 & 1.20 & 1.85 & 1.01 & 0.76 & 3.386 & 0.001 \\
\hline $\begin{array}{l}\text { 6. Boys are more likely } \\
\text { than girls to use com- } \\
\text { puters when they grow } \\
\text { up. }\end{array}$ & 2.90 & 1.19 & 2.00 & 1.19 & 0.90 & 3.676 & 0.000 \\
\hline $\begin{array}{l}\text { 7. Girls are more likely } \\
\text { than boys to use com- } \\
\text { puters when they grow } \\
\text { up. }\end{array}$ & 1.85 & .97 & 2.67 & 1.33 & -0.82 & -3.315 & 0.002 \\
\hline
\end{tabular}

came to girls being more likely to have a partner or less likely to use mechanical skills with computers, gendered expectations persisted. These gender differences persisted throughout the study. When comparing mean pretest and posttest differences in girls' and boys' attitudes, there was only one statistically significant change. In the final analysis, both sexes reported that girls were not more likely to use computers in their adult lives. It may be the case that girls developed more realistic attitudes about their own future technological use while boys shifted to less negative views toward females' competency (girls' mean change = -.33 ; boys' mean change $=.24$ ) .

For girls, there were positive attitudinal shifts about female competency. At the close of the spring semester, girls no longer believed that boys used mechanical skills with computers more than they did (pretest mean $=2.61$; posttest $=2.03$ ). They were firmly convinced that boys were not more technologically sophisticated (pretest mean $=1.83$; 
posttest mean $=1.36$ ). They were resolute in their position that boys were not more likely to use computers as adults (pretest mean $=2.00$; posttest mean $=1.58$ ). In regard to boys' attitudes about the relevance of technology, their views did not shift from time 1 to time 2 .

Comparisons of pretest and posttest results revealed that boys and girls did not differ in the way they felt about using computer technologies at home or at school. No statistically significant changes were noted in boys' attitudes over time. Girls only differed on one variable. They evidenced less support for using MicroWorlds every day at school (pretest mean $=3.26$; posttest mean $=2.71$ ) at completion of the study.

\section{IMPLICATIONS FOR FEMALES}

Our study suggests that both sexes are thriving in this Lego/Logo environment. Both groups view computer use as important for completing schoolwork and for future job or career roles. In contrast to studies in the literature of males holding dominance as computer users, females in this classroom report that they "think they can" be competent in using technology. However, boys remained convinced of their own technological superiority. Boys held to their beliefs that they played more with games and motors, didn't ask for help very much, and were generally better at using computers than girls, and were more likely to use computers in the future. Boys reported a slight reduction in their negative views of females. On the other hand, this intervention helped girls eliminate some of their gendered beliefs. Girls reported that they were just as capable with technology and the construction of motorized computer projects as boys, and as adults, that boys would not dominate computer use. Girls gained new confidence in their use of technology and more realistic expectations. It seems promising that the grade 1-5 girls in this study will refuse to be "marginalized" in later grades, such as middle school and high school, or even in future life experiences using the computer. However, continued interventions are critical to the development of skills, competencies, attitudes, and decision-making of females for success in later years.

Finally, these findings may benefit teachers in contemporary classrooms as they make meaningful and lasting impressions on elementary learners, particularly females, as they use technology for problem solving. The teacher's role in a problem-centered classroom is absolutely critical. Moursand (2002) asserts that teachers tend not to teach problem solving, as is frequently assumed. However, intentional use of com- 
puter technology with clearly defined goals to think through problems, gather and organize materials, and systematically approach tasks has the potential to empower students to learn differently according to this study. Effective teacher strategies influence children's ability to ask questions, take risks, figure things out, plan ahead, seek challenges, become persistent, develop self-reliance, and approach their work in a flexible manner. In addition, these strategies invite females to use their intellectual abilities. Importantly this approach allows males to acknowledge that girls can program, design structures, and analyze operations. In summary, because effective use of technology is central to the mission of many educational institutions, this study suggests that females are competent using computers for problem-solving programming activities at a young age and that teachers are important to the development of individual potential to use computers effectively in a classroom environment.

\section{REFERENCES}

AAUW. (1998). Gender gaps: Where schools still fail our children. Washington, DC: American Association of University Women Educational Foundation.

Beisser, S. R. (1999). Constructivist environments inviting computer technology for problem-solving: New junctures for female students. Unpublished doctoral dissertation, Iowa State University, Ames, IA.

Beisser, S. R. (1999-2000, Winter). Females and technology: Lack of equity for gifted adolescent females. National Association for Gifted Children Computers and Technology Division, NAGC Newsletter, Washington, DC.

Casey, M. B., \& Tucker, E. C. (1994). Problem-centered classrooms: Creating lifelong learners. Phi Delta Kappan, 76(2), 139-143.

Fennema, E. (1990). Justice, equity and mathematics education. In F. Fennema \& G. Leder (Eds.), Mathematics and gender (pp. 1-9). New York: Teachers College Press.

Harel, I., \& Papert, S. (1991). Constructionism. Norwood, NJ: Ablex.

Klein, S., \& Ortman, P. (1994, November). Continuing the journey toward gender equity. Educational Researcher, 23(8), 13-21.

Kahle, J. B., \& Meece, J. L . (1994). Research on gender issues in the classroom. In D. Gabel (Ed.), Handbook of research in science teaching and learning (pp. 542-557). Washington, DC: National Science Teachers Association.

Maddux, C. D., \& Cummings, R. (1999). Constructivism: Has the term outlived its usefulness? Computers in the Schools, 15(3/4), 5-10.

Mark, J. (1992, June). Beyond equal access: Gender equity in learning with computers. Women's Educational Equity Act Publishing Center Digest, 5-9.

Meece, J. L., \& Eccles, J. S. (1993). Introduction: Recent trends in research on gender and education. Educational Psychologist, 28(4), 313-319. 
MicroWorlds 2.03®. (1997). Highgate Springs, VT: Logo Computer Systems Inc. Retrieved September 8, 2004, from http://www.lcsi.ca.

MicroWorlds Pro®. (2000). Highgate Springs, VT: Logo Computer Systems Inc. Retrieved September 8, 2004, from http://www.lcsi.ca.

Lego ${ }^{\circledR}$ MindStorms ${ }^{\mathrm{TM}}$. (1998). Enfield, CT: LEGO Systems, Inc. Retrieved September 8, 2004, from http://legomindstorms.com.

MIT Epistemology and Learning Group. (2000). Retrieved September 8, 2004, from http://el.www.media.mit.edu/groups/el/elProjects.html.

Moursand, D. G. (2002, October 28). Brief introduction to roles of computers in problem-solving. Retrieved November 8, 2002, from University of Oregon, Oregon Technology in Education Council: http://darkwing.uoregon.edu/ moursund/SPSB/

Papert, S. (1980). Mindstorms: Children, computers and powerful ideas. New York: Basic Books.

Papert, S. (1993). The children's machine: Rethinking school in the age of the computer. New York: Basic Books.

Papert, S. (1999). Vision-making, new technologies, and powerful ideas in education. A talk at Heartland Area 11 Educational Agency/Drake University, Des Moines, IA: April 30, 1999.

Piaget, J. (1924). Judgment and reasoning in the child. Atlantic Heights, NJ: Humanities Press.

Roblyer, M.D. (May, 2000). Digital desperation: Reports on a growing technology and equity crisis. Learning and Leading with Technology, 27(8), 50-61.

Sternberg, R. J. (1994). Answering questions: Questioning answers. Phi Delta Kappan, 76(2), 136-138.

Sutton, R. E. (1991). Equity and computers in the schools: A decade of research. Review of Educational Research, 61, 475-503.

Title IX at 25: Report card on gender equity. (1997, June). National Coalition for Women and Girls in Education.

Turkle, S. (1988). Computational reticence: Why women fear the intimate machine. In C. Kramarae (Ed.), Technology and Women's Voices. New York: Routledge \& Kegan Paul.

Wellesley College Center for Research on Women. (1992). The AAUW report: How schools shortchange girls. Washington, DC: American Association of University Women. 